\title{
GEOLOGIC MAP OF THE HEART BUTTE QUADRANGLE, MORTON AND GRANT COUNTIES, NORTH DAKOTA \\ By
}

E. Vernon Stephens

COAL INVESTIGATIONS

MAP C -53

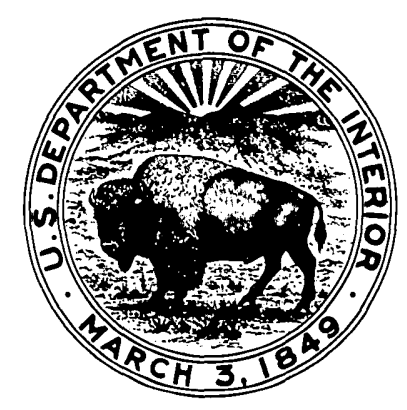

